\title{
SUBSIDIARITY OR FREEDOM OF ASSOCIATION? A PERSPECTIVE FROM LABOR LAW
}

\author{
Alan Bogg*
}

\section{Introduction}

The principle of subsidiarity has long been central to political deliberation about the regulation of work. ${ }^{1}$ Historically, it reflected "a tangible concern for the economic rights of workers as they sell their labor on the market." 2 The activity of work has the potential either to uplift or destroy the human spirit. Where work is "decent work," the worker can exercise her imagination, initiative and creativity in the workplace. ${ }^{3}$ The sphere of work also provides an opportunity for workers to learn the norms of reciprocity and solidarity through trade union participation, with trade unions functioning as vital mediating institutions interposed between the market and the state. Through collective bargaining, workers are empowered to create and shape the norms that regulate their working life. Where work is degrading, consisting of mindless and monotonous tasks and in circumstances of economic deprivation and insecurity, the moral consequences for human beings can be catastrophic. The eclipse of independent trade unionism in contexts of degrading work leads to further disempowerment, anomie, and a loss of collective selfmastery over the terms under which employment is conducted. Such work is an affront to the dignity of human beings, denying workers the opportunity to forge a life for themselves in circumstances of self-respect. ${ }^{4}$ Subsidiarity contributes to the promotion of decent work through its identification of the fundamental point of all coordinated human activity, including productive economic activity, which is to enable each human being to participate as fully and actively in living their own life: "anyone who is never more than a cog in big wheels turned by others is denied participation in an important aspect of human wellbeing." "5

\footnotetext{
* Fellow of Hertford College and Professor of Law, University of Oxford. Email: alan.bogg@hertford.ox.ac.uk.

${ }^{1}$ There are multiple accounts of subsidiarity. For an account of the varieties of subsidiarity, see Andreas Follesdal, "Survey Article: Subsidiarity," Journal of Political Philosophy 6 (1998): 190-218. This article will focus on the account of subsidiarity described by Follesdal as "catholic personalism" (207). While this account of subsidiarity has been central to Catholic social philosophy, I avoid the terminology of "catholic" to avoid any suggestion that its tenets cannot be endorsed from a secular perspective. It is nevertheless undeniable that its development has been influenced by a series of Papal encyclicals concerned with the requirements of social justice. Nor is there a single version of "catholic personalist" subsidiarity. As this article demonstrates, there are a variety of instantiations even of this "type" of subsidiarity.

2 Robert K. Vischer, "Subsidiarity as a Principle of Governance: Beyond Devolution," Indiana Law Review 35 (2001): 133.

${ }^{3}$ The term "decent work" is attributable to the concept's use by the International Labour Organisation (ILO) which launched its "Decent Work Agenda" in 1999. See ILO, Decent Work: Report of the DirectorGeneral (Geneva: International Labour Organization, 1999). The Decent Work Agenda is examined in Bob Hepple, Labour Laws and Global Trade (Oxford: Hart, 2005) 63-66.

${ }^{4}$ On the nature of work as a form of human good, see A L Bogg, "Only Fools and Horses: Some Sceptical Reflections on the Right to Work," in The Right to Work: Legal and Philosophical Perspectives, ed. Virginia Mantouvalou (Oxford: Hart; 2015), 152-159.

${ }^{5}$ John Finnis, Natural Law and Natural Rights, 2d ed. (Oxford: Oxford University Press, 2011), 147.
} 
Trade unions occupy a focal position in the constitution of the subsidiarity principle. As Vischer has argued, "unions are the most effective structures for mediating between individual workers and the largely impersonal and unforgiving marketplace." ${ }^{\circ}$ Thomas C Kohler has also developed a highly sophisticated set of arguments, basing his defense of collective bargaining and autonomous trade unionism on the subsidiarity principle. ${ }^{7}$ Like many other mediating associations in civil society, trade unions have been in precipitous decline in the United States and the United Kingdom. The decline of trade unionism seems to be part of a wider pattern of decline of social capital in civil society, captured under the troubling slogan of "bowling alone." 8 This has given the subsidiarity principle a renewed relevance in the urgent quest for an enduring set of solutions to the crisis faced by trade unions and the workers that they represent.

This article will explore the political possibilities offered by the subsidiarity principle in the sphere of labor law reform. Like many political principles, the subsidiarity principle is compatible with a diverse range of political programs. Different versions of the subsidiarity principle display different emphases, which in turn reflect the deeper political alignments of the protagonists invoking the principle. In some versions of subsidiarity, for example the vision articulated by Pope John Paul II, the principle reflects a conservative concern to restrict the coercive power of governmental authority. ${ }^{9}$ The subsidiarity principle thus opposes what it regards as the undue encroachment of state socialism on human freedom. Mediating structures in civil society exist as a plural and autonomous source of power that operates as a check on government. The free market itself is defended insofar as it "recognizes the fundamental and positive role of business, the market, private property, and the resulting responsibility for the means of production, as well as free human creativity in the economic sector." ${ }^{10}$ In this political vision of society, the subsidiarity principle is a principle of limited government. It thereby emphasizes the state's duties of non-interference in the autonomous networks of civil society. Where social functions are capable of being performed through decentralized associations, it is an injustice for the state to take over those functions. ${ }^{11}$ The organizational autonomy of associations is a value of particular importance in conservative versions of the principle, blocking the absorption of voluntary associations and personal self-assistance by an overweening state.

Other accounts of the subsidiarity principle have emphasized the need for active governmental support for civil society in order to promote the self-governing capacities of

\footnotetext{
${ }^{6}$ Vischer, "Subsidiarity as a Principle of Governance," 134.

7 Thomas C. Kohler, "Civic Virtue at Work: Unions as Seedbeds of the Civic Virtues," in Seedbeds of Virtue: Sources of Competence, Character and Citizenship in American Society, ed. Mary Ann Glendon and David Blankenhorn (London: Madison, 1995), 147.

8 The leading work in this vein is Robert D. Putnam, Bowling Alone: The Collapse and Revival of American Community (New York: Simon and Schuster, 2000). The significance of community in the sphere of work has been explored in Cynthia Estlund, Working Together: How Workplace Bonds Strengthen a Diverse Democracy (Oxford: Oxford University Press, 2005).

'John Paul II, Centesimus annus (1991) para. 48, cited Vischer, "Subsidiarity as a Principle of Governance," 112.

${ }^{10}$ John Paul II, Centesimus annus, para 42, cited in Vischer, "Subsidiarity as a Principle of Governance," 11213.

${ }^{11}$ Finnis, Natural Law and Natural Rights, 159, where he suggests of subsidiarity that "being a matter of right (justice), not merely efficiency, it is obviously closely related to what many people refer to as the right to liberty."
} 
associations. ${ }^{12}$ The state has a special responsibility to support the common good of the political community. This extends to "the right and the duty to intervene in the economic sphere in order to foster justice between capital and labor." ${ }^{\prime 13}$ This vision of subsidiarity places greater emphasis on the perfectionist role of the state in supporting the voluntary associations of civil society. Unregulated labor markets can be a source of unfreedom for workers. Free markets could also undermine and erode the institutions of civil society, such as the family or trade unions. This requires the state to take active steps to "empower" mediating institutions such as trade unions, supporting their capacities to operate as selfgoverning entities in society: "the government has a responsibility to protect the independence and vitality of unions so that they, in turn, may empower society's workers." ${ }^{14}$ Without perfectionist state support for groups such as trade unions, the associations of civil society might wither or even disappear. ${ }^{15}$ The history of labor relations is testament to the fact that associative activity cannot simply be taken as a "given" by states that care about the moral ecology of a society. A vibrant civil society is a fragile achievement that requires nurturing by perfectionist state support.

Across its history, the subsidiarity principle has inspired both anti-Marxists and anti-capitalists. It is not surprising that subsidiarity sometimes appears to have a chameleon-like quality as a principle of governance, registering across a wide political spectrum. In truth, it is false to present the subsidiarity principle as requiring a choice between its role as a source of restraint on state action and its role as a justification for perfectionist state action. Most philosophical accounts identify the principle as encompassing both constraint and perfectionism. ${ }^{16}$ Nevertheless, different philosophical accounts do tend to place greater emphasis on one or other of its facets.

This article will engage principally with the work of John Finnis, who has provided a rigorous and sophisticated account of the subsidiarity principle in his work on political and legal philosophy. It will do so from the perspective of labor law. This disciplinary perspective is useful, not least because practical problems of labor have been central to the historical development of the subsidiarity principle. Furthermore, the subsidiarity principle does not function so as to provide precise blueprints for solving regulatory problems. It is as much concerned with the practical craft of governing well and navigating difficulties in the real world, as it is with the drawing of precise philosophical lines and distinctions. Reflecting back on the philosophical discussions using practical examples from labor law may enable us to see the philosophical difficulties in a new light, and to identify weaknesses that might otherwise remain hidden. Using this focus, I will argue that there is too much constraint and not enough perfectionism in Finnis's account. In short, Finnis's version of

\footnotetext{
12 Vischer, "Subsidiarity as a Principle of Governance," 113-116.

${ }^{13}$ Frederick Crosson, "Catholic Social Teaching and American Society," in Principles of Catholic Social

Teaching, ed. David Boileau (Marquette University Press, 1998), 169, cited in Vischer, "Subsidiarity as a Principle of Governance," 114.

14 Vischer, "Subsidiarity as a Principle of Governance," 138.

${ }^{15}$ For such a "perfectionist" argument in the context of trade unions, see K. D. Ewing, "The State and Industrial Relations: 'Collective laissez-faire' Revisited,” Historical Studies in Industrial Relations 5 (1998): 1-31. This is supported by the work of perfectionist liberals such as Joseph Raz, who argues that many social forms providing valuable options for citizens depend upon perfectionist state support: see Joseph Raz, The Morality of Freedom (Oxford: Oxford University Press, 1986), 162.

${ }^{16}$ See the perceptive discussion of this feature of subsidiarity in Paolo G. Carozza, "Subsidiarity as a Structural Principle of International Human Rights Law," American Journal of International Law 97 (2003): 44.
} 
the subsidiarity principle represents an excessively conservative version of its implications, and this undermines its utility as a political principle for reconfiguring the norms and institutions of labor law. The biggest political risk to trade unions in civil society now lies in state indifference to their fate, rather than coercive state interference with the autonomy of groups.

In section II, the role of subsidiarity as a "negative" constraint on state action is examined. It is reflected in Finnis's argument that the state should "never" (or only "exceptionally") "take over" the "management," "direction," or "formation" of voluntary associations in civil society. ${ }^{17}$ This negative aspect of subsidiarity has been given particular emphasis where the subsidiarity principle has been harnessed in conservative political projects. I identify some difficulties in its role as a principle of constraint. Many of the distinctions at the heart of subsidiarity as constraint lack clarity. While it is important that the state respects the organizational autonomy of groups in civil society, these political concerns are better addressed through the familiar techniques contained in the right to freedom of association. In section III, the role of subsidiarity as a "positive" perfectionist principle is examined. Here I argue that Finnis's account of the subsidiarity principle is too restrictive of perfectionist state support, and I suggest some ways in which the principle might be reformulated so that it allows greater scope for perfectionist intervention.

The big question that runs through section IV of this article is the following. In response to the precipitous decline of trade unions and collective bargaining, labor lawyers are now focusing their attention on freedom of association as a source of restoration for labor unions. Across the world, trade unions have secured remarkable advances in supporting collective bargaining and the ability to strike through constitutional litigation under general freedom of association guarantees. Constitutional litigation is no panacea. Supreme court justices cannot wave a magic wand and make workers willing to organize, or employers willing to bargain with representative trade unions. Yet there is little doubt that rights-based litigation has provided a beacon of hope for workers and trade unions looking over the edge and staring into the precipice of a world of work without mediating institutions.

So does this mean that subsidiarity should be dispensed with as a normative principle in labor law? In section IV I argue that this would be a big mistake. Subsidiarity continues to provide insights of profound significance into the nature and value of associational activity. Without the supplementation of subsidiarity, there is a danger that freedom of association will be developed in directions that are not in fact conducive to a flourishing civil society. The danger is not fanciful. The article examines some recent attempts to elucidate the nature of freedom of association in the sphere of labor law, and it identifies a number of ways in which missteps in philosophical arguments could have been avoided through a greater engagement with the insights of subsidiarity. Consequently, labor lawyers would do well to regard subsidiarity as a structuring principle that shapes the interpretation and development of freedom of association. Subsidiarity or freedom of association? The answer, for labor lawyers at least, must surely be both.

\footnotetext{
${ }^{17}$ John Finnis, "Limited Government," in Finnis, Human Rights and Common Good, Collected Essays: Volume III (Oxford: Oxford University Press, 2011), 89-90.
} 


\section{Subsidiarity as a Constraint on State Action}

According to Finnis, the subsidiarity principle operates as a constraint on the scope of legitimate state action. It is thus a principle of limited government. Following a discussion of the "common good" in his essay "Limited Government," Finnis explains the principle in the following way:

True too, its [the common good's] proper range includes the regulation of friendships, marriage, families, and religious associations, as well as all the many organizations and associations which, like the state itself, have only an instrumental (e.g. an economic) common good. But such regulations of these associations should never (in the case of the associations with a non-instrumental common good) or only exceptionally (in the case of instrumental associations) be intended to take over the formation, direction, or management of these personal initiatives and interpersonal associations. ${ }^{18}$

In an important critical engagement with Finnis's work, Les Green has described this principle as the "instrumentality" principle. ${ }^{19}$ This reflects Finnis's apparent concern to demarcate an absolute protected zone around "non-instrumental" associations, shielding them from interference by the "instrumental" association of the state. According to Green, the "key idea is that many associations of civil society—things like families, friendships, churches, universities, or partnerships-instantiate goods that political life does not. The state is an instrument, a means; the associations of civil society involve intrinsically good ends. That being so, governments should let them be." ${ }^{20}$

It is certainly true that Finnis articulates the constraint on the state "taking over" "non-instrumental" associations as an absolute constraint. However, his account also specifies that the "taking over" of "instrumental" associations by the state should only be permitted "exceptionally." While this is a defeasible rather than an absolute constraint, "exceptionally" seems to envisage a very strong presumption in favor of the organizational autonomy even of "instrumental" associations. In his more recent work, Finnis has also suggested that it is unhelpful to describe the political common good as "instrumental" because such a term "does not well fit a form of human cooperative associating-political governance-which cannot be done well, or even adequately, without both a measure of pervasive political friendship and a correct and widely held conception of, and willing favor for, the all-inclusive common good of the political community." ${ }^{21}$ Hence the state is not simply an instrument. Like many of the associations in civil society, the state embodies both instrumental and non-instrumental value. Thus, we need to be careful in describing the

\footnotetext{
18 Ibid.

${ }^{19}$ Leslie Green, “The Nature of Limited Government," in Reason, Morality, and Law: The Philosophy of John Finnis, ed. John Keown and Robert P. George (Oxford: Oxford University Press, 2013), 194.

${ }^{20}$ Ibid., 193.

${ }^{21}$ John Finnis, "Reflections and Responses," in Keown and George, Reason, Morality, and Law, 514. This modification of his account of common good, as encompassing both intrinsic and instrumental aspects, is likewise suggested in the postscript to the second edition of Natural Law and Natural Rights, 459.
} 
constraint in terms of "instrumentality." States themselves instantiate weighty "noninstrumental" values; and even "instrumental" associations may only be subject to a "taking over" in (undefined) "exceptional" circumstances.

Nevertheless, the defeasibility of the constraint does vary between "noninstrumental" associations ("never") and "instrumental" associations ("exceptionally") in civil society. The distinction and its relevance to subsidiarity is an intriguing one. The first difficulty is to understand why the "non-instrumentality" of an association triggers the absolute constraint, especially given Finnis's reflections on the source of the subsidiarity principle. In explaining its source, Finnis argues that "human good requires not only that one receive and experience benefits or desirable states; it requires that one do certain things, that one should act, with integrity and authenticity; if one can obtain the desirable objects and experiences through one's own action, so much the better." ${ }^{22}$ It is not at all clear why the "non-instrumental" character of an association should lead to elevated protection. According to Finnis, the individual's choosing and realization of commitments, through "personal inventiveness and effort in projects," 23 is a vital aspect of human well-being. It is only where individuals participate in shaping their own lives through initiative and selfhelp, often in collaboration with others, that a human life is led fully. Yet the formulation and execution of personal projects and commitments seems as likely to occur in "instrumental" associations, such as political groups, neighborhood associations or trade unions, as in "non-instrumental" associations such as families or friendships. A more relevant consideration would seem to be the scale of the association: state interference with larger organizations that are more remote from the individual actions of members might be less disruptive of an individual's self-constituting action than interference with smaller organizations. Yet scale and remoteness does not seem to be strongly correlated with the instrumental character of an association. Whatever reason there might be for singling out "non-instrumental" associations for absolute protection, the source of the subsidiarity principle in enabling self-constituting action in civil society does not seem to be one of them.

Perhaps we need to look elsewhere for an explanation. Another argument might be that "intrinsic" value is of more importance than "instrumental" value; hence interfering with "non-instrumental" association is more disruptive to human well-being. Les Green offers some skeptical reflections on this claim in the following terms: "Assume that the communal and cooperative goods of civil society are intrinsically good. It does not follow that they are very good. A pretty stone on a beach is intrinsically valuable, but not very valuable. On the other hand, even if political cooperation is only of instrumental value, it does not follow that it is of little value. On the contrary, it is of enormous value." ${ }^{24}$ Green's reflections on the nature of value seem on the mark. The "intrinsic"/ "instrumental" distinction does not reflect a scale of magnitude or importance. Finnis is of course rather more specific in singling out particular forms of "non-instrumental" association in demarcating his absolute constraint. He refers to "friendships, marriage, families, and religious associations." So whilst it is true that "intrinsic" value need not be very valuable,

\footnotetext{
${ }^{22}$ Finnis, Natural Law and Natural Rights, 147.

23 Ibid., 146.

${ }^{24}$ Green, “The Nature of Limited Government,” 195.
} 
the specific types of association singled out by Finnis are very valuable indeed. So the personal and intimate human relationships that go to constitute family, friendship and marriage have generally been regarded at the core of constitutionally protected freedom of association in the United States Supreme Court jurisprudence on freedom of association. ${ }^{25}$ Religious association is likewise treated as a special case of associational liberty, given the profound and transcendental significance of religious commitment to the lives of adherents. This has also been reflected in the distinctive constitutional treatment for religious associations. ${ }^{26}$ Where the state disrupts the organizational autonomy of such associations through "taking over," the corresponding disruption of the moral and personal autonomy of individuals demands anxious scrutiny. This may have less to do with the "intrinsic" nature of the association, however, and more to do with the special value of intimate and religious associations in personal and moral autonomy.

A further reason for skepticism is that the distinction is also very difficult to apply in the complex and messy terrain of civil society. Many groups seem to display elements of both "instrumental" and "intrinsic" value. Thus, in Bob Jones University v. United States, the Supreme Court upheld the denial of tax exemption to Bob Jones University on the basis that the institution practiced race discrimination in its prohibition of interracial dating between students. ${ }^{27}$ This student policy was based upon a sincere belief in the Biblical proscription of miscegenation. In applying the subsidiarity constraint, is Bob Jones University best characterized as an "instrumental" or a "non-instrumental" association? As a university, it may be regarded as possessing an instrumental character. Universities exist to facilitate the pursuit of the good of knowledge, and may be regarded as an instrument in furtherance of that end. ${ }^{28}$ As an institution based upon shared religious commitment, it may be regarded as having a "non-instrumental" character. It is surely both. On Finnis's account, the characterization is significant because it determines whether an institution like Bob Jones University possesses an absolute or defeasible claim against the state "taking over" its "management" or "control." Yet how to characterize such an association deflects attention away from more pressing substantive questions. In her perceptive discussion of Bob Jones University v. United States, for example, Gutmann explores the different permutations that might arise in this context. ${ }^{29}$ While the preservation of fair educational opportunities might justify state interference in Bob Jones University's student policies, the argument might be less compelling if Bob Jones Church forbade miscegenation amongst its congregation. The arguments might shift again if the Church

\footnotetext{
${ }^{25}$ The distinction between intimate and non-intimate associations was a strong feature of the judicial reasoning in Roberts, Acting Commissioner, Minnesota Department of Human Rights, et al v. United States Jaycees 468 U.S. 609 (1984), which concerned the freedom of the Jaycees (a large-scale organization for social and commercial networking) to discriminate against women in its membership criteria. The Supreme Court determined that the Jaycees's freedom of association was amenable to restriction to ensure nondiscriminatory access for women to the commercial opportunities offered by the association. For critical discussion, see George Kateb, "The Value of Association," in Freedom of Association, ed. Amy Guttman (Princeton, NJ: Princeton University Press, 1998), 35.

${ }^{26}$ Kent Greenawalt, "Freedom of Association and Religious Association," in Gutmann, Freedom of Association, 109.

27461 U.S. 574 (1983).

${ }^{28}$ Green, “The Nature of Limited Government," 197.

${ }^{29}$ Amy Gutmann, "Freedom of Association: An Introductory Essay," in Gutmann, Freedom of Association, 68.
} 
was enforcing employment policies against its office staff. The considerations are highly sensitive to context. Again, it is not clear how the "instrumental"/"non-instrumental" distinction advances the difficult assessment of what is legitimate by way of state intervention in the group's autonomy.

Perhaps Finnis might respond that we would do better to consider the nature of the distinction between "regulation" and "taking overs," as a more reliable basis for assessing the limits of state intervention. Regulation may be permissible; intervention with the "aim to take over their formation, direction, or management" is not. Finnis explains the distinction in the following way:

Just as, for example, the privileges of the English Parliament exclude any management, direction, control, or takeover of either House by the courts or the executive, yet do not entail that the criminal law and its officers have no jurisdiction over acts and events within Parliament, so state government and law have some proper regulatory role in relation to even the internal affairs of families and religious associations. The limit excludes any aim to take over their formation, direction, or management. ${ }^{30}$

Does this exclusion of intervention with "any aim to take over their formation, direction, or management" provide a coherent limit on the legitimate scope of state interference? It may be objected that the formula "take over their formation, direction, or management" is too vague. ${ }^{31}$ For example, British trade unions have long been subject to the state imposition of mandatory balloting procedures for the maintenance of political funds, the election of specified union representatives, and as a precondition of lawful strike action. ${ }^{32}$ Is this a "taking over" of the "management" and "direction" of the trade union? It certainly involves extensive state interference with the internal organization and constitution of the group. Even if trade union ballots are characterized as "regulation," what if the state imposed statutory ballots to elect archbishops in a church? I suspect that we would be much more likely to characterize this as a "taking over" of the "management" of the church, simply because the interference is obviously unjust. If we take this step, however, we might well wonder at the utility of the concept of a "taking over." It seems to be operating as a placeholder for a set of underlying normative considerations that are not being fully articulated. We might do better to address those normative arguments explicitly and transparently, rather than mediating them through the rather opaque notion of a "taking over" as a conclusory label.

Moreover, the nature of the moral objection to "taking over" is never made explicit. Take an example of an "intrinsic" association such as a church. The officials of the church have been involved in corrupt and abusive activities that violate various criminal laws. Finnis certainly concedes that the jurisdiction of the criminal law would extend to the activities of the officials. For Finnis, state coercion can be justified by the need to regulate "interpersonal relations and external acts which impact directly or indirectly on

\footnotetext{
${ }^{30}$ Finnis, "Reflections and Responses", 514-515.

${ }^{31}$ Finnis acknowledges that the distinction is "vague" albeit "not without content": ibid, 515.

${ }^{32}$ For a general account of these complex statutory provisions, see A.C.L. Davies, Employment Law (Harlow, UK: Pearson, 2015), chs. 11 and 13.
} 
others." 33 Why should the jurisdiction of the state end here with the enforcement of criminal offences against wrongdoers? A state might make provision for associations to be placed in a form of temporary administration in these circumstances, until good order is restored to the association's internal governance. This would involve a temporary "taking over" of the "management" of the church, until such time as the church is capable of being run again by its own members. This form of intervention might salvage the group, rather than condemn it to extinction. Where the "taking over" is confined to what is strictly necessary to enable the association to become self-governing again, this would seem to be consistent with the rationale of the subsidiarity principle. Certainly, it is difficult to see what would be objectionable about a "taking over" in these circumstances, yet it would seem to be ruled out by Finnis's version of the principle.

In a recent symposium on his work, Finnis has now framed the "subsidiarity" enquiry in the following way: "If we ask why the largely instrumental character of state government limits or tends to limit its jurisdiction over non-instrumental associations and the persons who are their members ... the answer at least in large part will take the form of reversing the challenge. It is for the state's government and law to prove that its jurisdiction rightly reaches so far into the lives of those persons and associations whose good is more intrinsic than its." 34 What Finnis appears to be conceding here is that the constraint generated by the subsidiarity principle is not absolute or "exceptionless." It is instead formulated as a heavy argumentative burden on the state to justify its intervention into the lives of persons and associations in civil society. In effect, there is a strong presumption against state interference with the associational autonomy.

In my view, this shift is a very welcome one. It points towards a much more particularized evaluation of the "burdens of interference" against the "burdens of noninterference" in civil society. ${ }^{35}$ In fact, this style of reasoning is already well established in law and political philosophy as a basis for specifying the limits of a group's claim to organizational autonomy, under the guise of the right to freedom of association. It forms part of what Green has described as "protected sphere" considerations, such that "certain decisions and activities are to be reserved for individuals and groups, especially those that involve matters important to their moral independence and autonomy. These are protected by familiar individual and collective rights." 36 Freedom of association is an important part of this "protected sphere" zone, especially in its protection of the right of groups to organizational autonomy. This right will be particularly weighty for groups such as religious, expressive or intimate associations, but even here it is—rightly—not absolute. For example, De Marneffe gives the example of a church that refuses to permit women to be clergy on the basis of uncodified local traditions rather than transcendental beliefs. ${ }^{37}$ Such discriminatory practices should not be shielded by the subsidiarity principle or indeed

\footnotetext{
${ }^{33}$ Finnis, Natural Law and Natural Rights, 459. This principle, based in Finnis's reading of Aquinas, shares an affinity with the "harm principle." Like the concept of "harm," the notion of direct or indirect external impact requires further moral argument to fill out its content. For further discussion of this moralized character of "harm," see Raz, The Morality of Freedom, 414.

${ }^{34}$ John Finnis, “A Response to Harel, Hope, and Schwartz,” Jerusalem Review of Legal Studies 8 (2013): 156.

${ }^{35}$ A persuasive rendering of such a particularized account in these terms is set out and defended in Peter de Marneffe, "Rights, Reasons, and Freedom of Association," in Gutmann, Freedom of Association, 145.

${ }^{36}$ Green, "The Nature of Limited Government," 189.

${ }^{37}$ De Marneffe, "Rights, Reasons, and Freedom of Association," 156.
} 
any other principled limit on government action. The associational autonomy of groups such as the Jaycees or universities will generally be much weaker in the face of exclusionary practices that deprive citizens of economic and social opportunities for full participation in civil society. The right to freedom of association already encompasses all of this. It is not at all obvious what the subsidiarity principle adds as an additional constraint on state action, and the vagueness of its core elements means that it should be dispensed with as an independent principle. The necessary work is already being done through the familiar "protected sphere" considerations: freedom of association, sometimes supported by freedom of speech, freedom of religion and the right to privacy in the case of expressive, religious and intimate associations. Where this 'protected sphere' exists, subsidiarity adds nothing of use to the normative enquiry.

\section{Subsidiarity as State Perfectionism}

The subsidiarity principle is also a perfectionist principle. In its perfectionist guise, it envisages a role for the state in "assisting individuals and groups to coordinate their activities for the objectives and commitments they have chosen." This reflects the etymological roots of subsidiarity in the Latin term subsidium, or "help":

its purpose must be to carry out a function which the Jesuit social theorists of the early twentieth century taught us to call subsidiarity (i.e. helping, from the Latin subsidium, help): the function of assisting individuals and groups to co-ordinate their activities for the objectives and commitments they have chosen, and to do so in ways consistent with the other aspects of the common good of the political community. ${ }^{38}$

The perfectionism in subsidiarity is directed at assisting associations and individuals to help themselves, in order that individuals can lead lives of self-directed and self-constituting action. As we have seen, subsidiarity is also a principle of constraint. This principle of constraint requires that state intervention must never be intended "to take over the formation, direction, or management of the lower level personal initiatives and interpersonal associations." Does this principle of constraint restrain state perfectionism to an excessive degree? It would certainly seem to rule out perfectionist intervention that amounted to a "take over" of the "formation, direction, or management" of an association.

In an interesting set of reflections on subsidiarity, Daniel Schwartz has described subsidiarity as embodying an "anti-state bias," at least in the form of the principle defended by Finnis. ${ }^{39}$ In support of this restricted perfectionist reading of Finnis, Schwartz offers an interesting example of what he regards as an instance of unjust perfectionism:

Suppose that you see your child trying to build a tower with Lego bricks. You see that the base is defectively built and know the tower will not reach a great height.

\footnotetext{
${ }^{38}$ Finnis, "Limited Government," 90.

${ }^{39}$ Daniel Schwartz, "Perfectionism and Subsidiarity: Comments on John Finnis' Human Rights and the Common Good,” Jerusalem Review of Legal Studies 8 (2013): 128.
} 
You take over and build a very tall and stable tower. Your child however is very upset, and rightly so. The whole point of Lego is the activity of building, surmounting the challenges, learning along the way, improvising solutions, and developing resourcefulness, and self-confidence. ${ }^{40}$

As it is with Lego, so perhaps it is with living a life. The failures are as integral to a welllived life as the successes. The realization of the basic goods in our lives requires our active participation and engagement in them: "human good requires not only that one receive and experience benefits or desirable states; it requires that one do certain things, that one should act, with integrity and authenticity; if one can obtain the desirable objects and experiences through one's own action, so much the better." ${ }^{41}$ Where the state intervenes and "takes over" a person's own initiatives and efforts in order to improve outcomes, it might be objected that the "beneficiary" of state intervention in fact suffers a serious injustice. Such intervention blocks the opportunity for her to participate fully in a basic good, it stifles the development of character and imagination that comes from personal commitment and active engagement in the world, and overall it stunts her human flourishing. According to Schwartz, this would even be true of "take overs" that are welcomed or even invited by persons and their associations: "Sometimes welcome offers of help hinder people's capacity to help themselves. The offer of a shortcut that will save a person from a strenuous uphill path of self-building, and the many inevitable wrong turns, may be irresistible." ${ }^{2}$ The subsidiarity principle should therefore block such interventions too, however well-intentioned they might be. In his comments on Schwartz, Finnis has signaled his broad approval of Schwartz's account. ${ }^{43}$

In my view, the constraints on perfectionist state action envisaged by Schwartz and Finnis are too strict. To support this argument, I propose to use two specific examples of perfectionist state intervention from the trade union context, both of which appear to involve prohibited "taking overs" whilst having the practical effect of providing powerful support to autonomous trade unionism. Before doing so, however, the "Lego" example is instructive, for it is not at all obvious that the kind of intervention envisaged in Schwartz's example is necessarily objectionable. It seems true that comprehensive and indiscriminate invasions of a person's own efforts and initiatives, supplanting them through more efficient state provision, involves an unjust deprivation of opportunities to self-constitute and so flourish as a human being. Yet not all "taking overs" will be of this character. Where "taking overs" are narrowly targeted rather than global in their reach, and where this leaves citizens with a sufficient range of opportunities for self-constituting action in civil society, such interventions may not be objectionable. More particularly, and to stick with Schwartz's Lego example, the well-intentioned parent might teach the child how to build an impressive Lego structure by example. Once the child has watched how it is done, he may then have the confidence to try for himself. In this way, the "taking over" is a shortterm method of intervention, envisaged as a temporary expedient, and deployed with the intention of assisting the child to do his own Lego building in due course. The reasons in

\footnotetext{
${ }^{40}$ Ibid., 127.

${ }^{41}$ Finnis, Natural Law and Natural Rights, 147.

42 Schwartz, "Perfectionism and Subsidiarity," 127.

${ }^{43}$ Finnis, "A Response to Harel, Hope, and Schwartz," 156.
} 
favor of this kind of intervention might be particularly compelling where the guidance is in fact sought by the child, rather than foisted upon him unwillingly by an over-zealous parent. There is something troubling and a little callous where a parent leaves his child to flounder, especially after the child has asked for help. This is not at all the same as a stifling and unwanted intrusion by an overbearing parent anxious to demonstrate his own superiority in building elaborate Lego structures.

I propose two modifications to the strict constraints envisaged by Schwartz and Finnis. First, it may sometimes not be unjust to "take over" lower level personal projects and initiatives where that taking over is a temporary and short-term intervention with the specific purpose of assisting the association and its members to become self-supporting through voluntary action over the longer term. This is still perfectionist intervention designed to help associations and their members to help themselves, albeit through a shortterm sacrifice in the self-constituting activities of the association. Secondly, and contra Schwartz, there is a significant moral difference between welcome and unwelcome perfectionist intervention. Situations of non-voluntary "taking overs" to serve perfectionist goals, in the manner of usurpations by the state, are much more likely to be unjust than "voluntary" perfectionist "taking overs" that are sought or affirmed by the association. That is not to say that it will always be legitimate for the state to provide perfectionist support whenever it is sought or welcomed by an association. State support might be so global and pervasive that it becomes destructive of the individual initiatives and efforts of members of the association. These concerns may be particularly compelling where associations become dependent on external support and state provision, for this addiction to perfectionist support may be corrosive of the capacities for voluntary action that sustain associations in an enduring way. This will not be true of all instances of "voluntary" perfectionist interventions, however, and where it is not true, the consent of the association and its members to the perfectionist measure should be treated as a reason in favor of its legitimacy.

This may be supported by two specific examples of state intervention in UK labor relations. One of the central preoccupations of labor lawyers has been to explore the legitimate limits of perfectionist state support for trade union activity and collective bargaining. While this examination has often been marked by pragmatism rather than conducted as an exercise in political theory, the central quandary for labor lawyers is a familiar one to philosophers concerned with subsidiarity: in what circumstances does perfectionist state support for trade unions cross the line and become an illegitimate incursion into their internal "autonomy" and their freedom to operate as self-governing communities? During the middle decades of the twentieth century, the dissolution of autonomous groups in civil society (especially trade unions) by totalitarian governments meant that the balance between state perfectionism and group autonomy was not simply an opportunity for idle philosophical speculation. ${ }^{44}$ In the UK during this period, labor

\footnotetext{
44 The "father" of UK labor law, Otto Kahn-Freund, was a German Jew who fled the Nazis to come to the UK in 1933. His experience as a refugee fleeing totalitarianism in Germany shaped his intellectual outlook on labor law profoundly. He was intensely preoccupied with the "autonomy" of trade unions, and the political risks entailed by too much state perfectionism. See Ruth Dukes, "Otto Kahn-Freund and Collective Laissez-Faire: An Edifice without a Keystone?,” Modern Law Review 72 (2009): 220-46. See also
} 
lawyers were acutely aware of the political sensitivities surrounding excessive perfectionist intervention in trade union affairs. Even so, a wide variety of perfectionist measures were developed during this period. Whilst some of these involved a sacrifice of autonomyindeed a "taking over" by the state of regulatory functions - the measures were efficacious in supporting autonomous trade union activity.

The first perfectionist institutional measure to consider is "Wages Councils." 45 This envisaged an institutional arrangement whereby wages and other selected terms and conditions of employment would be set by a Council consisting of equal numbers of employers' representatives, employee representatives and independent members. The Council would issue proposals that could be made enforceable in individual contracts of employments through a Ministerial Order. It was not possible for the Minister to modify the content of such proposals, in order to protect the autonomy of the Council from state interference. Wages Councils were conceived as institutions to provide minimum wage standards in industries were union organization was weak or non-existent. These institutions were set up by Ministerial Order where the Minister was satisfied that adequate collective bargaining machinery did not exist. Indeed, it was possible for this to occur even in situations where the Minister of Labor anticipated a failure of existing bargaining structures. On the face of it, the operation of Wages Councils seems to involve a "take over" of the "formation, management or direction" of a trade union's collective bargaining activities. Where bargaining was non-existent, a Ministerial Order seems to involve a taking over of "formation" of collective bargaining; where bargaining was anticipated to fail, a Ministerial Order appears to be a taking over of "management or direction" of the trade union's self-governing activities.

Should we not regard Wages Councils as an instance of unjust perfectionism, rather like the overbearing father taking over the building of the Lego structure? Reflecting on the specific implementation of Wages Councils legislation, that characterization should be resisted. As Wedderburn has observed, Wages Councils provided "a training ground for bargaining" by simulating the autonomous processes of collective negotiation. ${ }^{46}$ This simulation of voluntary collective bargaining shaped the constitutional design of Wages Councils, with substantive wage-fixing undertaken by the worker and employer representatives themselves rather than imposed by governmental fiat. This was intended to provide a stimulus to voluntary collective bargaining once trade union organization reached a stage of sufficient strength and maturity. This was encapsulated in the striking claim that "the first objective of any Wages Council should be to commit suicide" once voluntary collective bargaining was established. ${ }^{47}$ The Wages Council performed an educative function, providing a substitute for collective bargaining through a statutory intervention, but with the objective of stimulating the growth of autonomous processes. In this way, the Wages Council is rather like the parent "taking over" the building of the Lego structure as a temporary measure, setting an example on how things are to be done

\footnotetext{
Mark Freedland, "Otto Kahn-Freund," in Jurists uprooted: German-speaking emigre lawyers in twentieth-century Britain, ed. Jack Beatson and Reinhard Zimmermann (Oxford: Oxford University Press, 2004), 299-324. 45 The classic account is F. J. Bayliss, British Wages Councils (Oxford: Blackwell, 1962). See also K. W. Wedderburn, The Worker and the Law, 2d ed. (Harmondsworth, UK: Penguin, 1971), 207-211.

46 Wedderburn, The Worker and the Law, 210.

${ }^{47}$ Ibid.
} 
so that parental guidance quickly becomes redundant. Where such "taking over" is aimed at helping associations to help themselves, designed as a temporary and short-term intervention (its primary objective "to commit suicide"), it should be regarded as an instance of legitimate perfectionism. ${ }^{48}$ Where in practice such institutions operate as impediments to voluntary collective bargaining and associational self-help, however, their legitimacy would be undermined. ${ }^{49}$

Another form of auxiliary intervention is "compulsory arbitration" whereby an external agency imposes binding norms on the employer and trade union, usually in the event of a failure to negotiate a first collective agreement. ${ }^{50}$ The political legitimacy of "compulsory arbitration" has been a matter of great controversy in labor law, and the subsidiarity principle provides an explanation for why that might be so. This is because compulsory arbitration seems to constitute a clear case of the state "taking over" the "direction" or "management" of the self-governing activities of trade unions and employers by imposing norms upon them, usually in the event of "bad faith" bargaining leading to a failure to reach agreement. Kahn-Freund once described compulsory arbitration as "incompatible with voluntary trade unionism," and this fortified his view that "it has a close affinity to Fascist legal institutions." 51 In other contexts, however, the technique of "first contract arbitration" has been proposed as a powerful intervention that is effective in promoting sustainable collective bargaining relationships in the face of employer hostility. ${ }^{52}$ This intervention avoids a situation where a trade union is awarded collective bargaining rights for the first time but is unable to secure a collective agreement in the face of employer intransigence. The imposed norms reflect what would have likely been agreed had the employer bargained in good faith with the trade union. As first contract arbitration, this is more in the manner of a short-term "taking over" of the "direction" of bargaining activities. This tends to promote an enduring autonomous bargaining relationship over the longer term.

In truth, "compulsory arbitration" is a term that encompasses a multitude of institutional arrangements, and there are significant normative differences between them. Unsurprisingly, these various schemes also encompass a multitude of possible sins and virtues displayed in different degrees. A number of points may be made here. First, KahnFreund reserved the deepest opprobrium for compulsory arbitration arrangements that prohibited strike action through criminalization. Viewed from the perspective of the subsidiarity principle, this opprobrium is warranted. It entailed the transformation of social

\footnotetext{
${ }^{48}$ Perhaps Finnis might respond that, as described, the Wages Council is not in fact a "take over." Given the ambiguities in the term "take over," such a move would be difficult to counter. It would then make matters turn on how we defined a "take over," which would not seem fruitful as a way of conducting an argument.

${ }^{49}$ For example, Wedderburn notes that such interventions did sometimes operate as a "barrier" rather than a "stimulant" to voluntary trade union activity. In such circumstances, the measure would involve an illegitimate interference with trade union autonomy. See Wedderburn, The Worker and the Law, 211.

50 So-called "first contract" arbitration has often been proposed as a measure to improve the effectiveness of US labor relations machinery. The seminal work in this vein is Paul C. Weiler, "Striking a New Balance: Freedom of Contract and the Prospects for Union Representation," (1984) 98 Harvard Law Review 98 (1984): 351-420.

51 Otto Kahn-Freund, “Collective Agreements under Wartime legislation,” Modern Law Review 6 (1943): 121.

52 Weiler, "Striking a New Balance."
} 
organizations pursuing their own purposes freely through collective bargaining into subordinated instruments of State policy. In Germany, such arrangements contributed to the destructive integration of free trade unions into the coercive apparatus of the State. ${ }^{53}$ The prohibition of strike action also failed to respect the critical role of the strike in facilitating workers' self-help through voluntary action. Secondly, the status of the arbitral body is also important to assessing the legitimacy of compulsory arbitration as a perfectionist technique. Where arbitrators are independent of state directives on economic and social policy, the dangers of compulsory arbitration leading to the absorption of free organizations into the state is reduced. Where ministerial directives bound the arbitrator, as had been the case under the Weimar system of compulsory arbitration, the eclipse of union autonomy proved to be politically dangerous and was the hallmark of a totalitarian state. $^{54}$

Thirdly, British labor law has experimented with forms of "unilateral compulsory arbitration" as a remedy for failures to bargain or disclose information for collective bargaining purposes. The intervention is "unilateral" in the sense that it will have the consent of one of the parties (i.e., the trade union) seeking the remedy against the employer, but it is "compulsory" in that the imposed norms were binding on the parties. ${ }^{55}$ The consent of the trade union is an important factor in assessing the legitimacy of the auxiliary measure, and attracts very different considerations to where compulsory arbitration overrides the autonomy of trade unions. Finally, Kahn-Freund has argued that "compulsory arbitration may have one effect if it is used as an ultima ratio and quite another if it supersedes bargaining and is intended to do so." ${ }^{56}$ For example, "first contract" arbitration is envisaged as a measure designed to render the need for it otiose because the parties subsequently engage with each other willingly. It is limited by reference to the first contract between the parties, to give the trade union an opportunity to be self-sustaining through autonomous worker action in subsequent iterations of the bargaining process. Furthermore, it is an intervention that is sought by the trade union, even if resented as an unwarranted intrusion by the employer.

In assessing the legitimacy of perfectionist intervention, then, the line between "state help" and "self-help" is not always clear-cut. Smart regulation may be targeted so as to help associations to help themselves more effectively. The history of "auxiliary" interventions to support trade unions provides many examples of such interventions. It may even sometimes be justifiable for the state to "take over" the functions of associations in limited ways where this is done in order to assist those associations to be self-supporting. There is no simple metric for determining whether such perfectionist measures are legitimate. As the discussion of "compulsory arbitration" demonstrates, this will depend upon a variety of factors: the extent to which the measure prohibits the freedom to strike of workers and trade unions; whether the arbitrator is independent and insulated from state influence; the extent to which one of the parties (usually the trade union) consents to

\footnotetext{
${ }^{53}$ For discussion of this feature of Kahn-Freund's work, see A. L. Bogg, The Democratic Aspects of Trade Union Recognition (Oxford: Hart, 2009), 23-26.

${ }^{54}$ Paul L. Davies and Mark R. Freedland, eds., Kabn-Freund's Labour and the Law, 3d. ed. (London: Stevens \& Sons, London, 1983), 148.

55 Ibid., 152.

56 Ibid.
} 
and welcomes the external intervention; and the duration and social effect of the intervention. The categorical nature of the prohibition of "taking overs" in the subsidiarity principle glosses over these relevant normative distinctions. It matters how a "taking over" is implemented in assessing whether it is a legitimate perfectionist intervention.

Other accounts of the subsidiarity principle are more forgiving of perfectionist intervention. For example, Crosson has argued that it is the state's responsibility "to assist the subsidiary groups in achieving their proper ends, and to implement those ends itself only temporarily in circumstances where the subsidiary group is, perhaps because of particular socio-economic conditions, incapable of functioning normally. This ... involves the state intervening-but temporarily and in limited fashion - to secure the goods of the partial community. ... Hence the state's intervention should aim at helping the subsidiary group regain the capacity to function for itself." 57 This framing of the subsidiarity principle would open up much more political space for the state to deploy a wide variety of perfectionist "auxiliary" interventions to support trade unions and restore collective bargaining, even if this extends to a "take over" of certain functions by the state. If subsidiarity is to remain relevant in an era of trade union decline, the perfectionist aspects of subsidiarity needs to be given much greater emphasis, and this requires a loosening of the constraints on state perfectionism to permit 'taking overs' in certain circumstances.

\section{Subsidiarity as a Structuring Principle of Freedom of Association}

Freedom of association now occupies center-stage as a legal strategy for reversing trade union decline. Litigation strategies in constitutional courts have been successful in utilizing freedom of association as a basis for developing rights to organize in trade unions, to engage in collective bargaining, and to strike. This turn towards litigation no doubt reflects a political judgement that workers and trade unions have become increasingly marginalized in the general democratic process.

While freedom from state interference in internal organization remains a significant freedom for trade unions, greater urgency has attached to securing the freedom to engage in core activities such as collective bargaining. Scholarly interest in freedom of association has been reinvigorated in many jurisdictions following a spectacular reversal of organized labor's fortunes in constitutional litigation. Constitutional jurisprudence in the Supreme Court of Canada has undergone a transformation following the constitutional recognition of the right to bargain collectively and the right to strike as elements in the Canadian Charter's general protection of freedom of association. ${ }^{58}$ The European Court of Human Rights has also been in the vanguard of a bold development of trade union freedoms, especially under Article 11 of the European Convention on Human Rights. ${ }^{59}$ Writing just

\footnotetext{
${ }^{57}$ Crosson, "Catholic Social Teaching and American Society," 170-171, cited in Vischer, "Subsidiarity as a Principle of Governance: Beyond Devolution,” 119.

${ }^{58}$ For an excellent account of these developments, see Judy Fudge, "Constitutionalizing Labour Rights in Canada and Europe: Freedom of Association, Collective Bargaining, and Strikes," Current Legal Problems 68 (2015): 267-305.

${ }^{59}$ Article 11 specifies that "Everyone has the right to freedom of peaceful assembly and to freedom of association with others, including the right to form and to join trade unions for the protection of his interests." The pivotal decision where the ECtHR recognized a fundamental right to collective bargaining
} 
over 25 years ago, Lord Wedderburn offered a pessimistic assessment of freedom of association as a constitutional basis for developing trade union rights. ${ }^{60}$ Judicial construction of freedom of association tended to configure it narrowly as a right for individuals to form and join associations. Wedderburn regarded this as a rather obtuse understanding of the freedom at stake in freedom of association in the field of labor law. Trade unions were ultimately purposive entities that existed to pursue vital protective goals on behalf of their members. That purposive understanding was largely absent from judicial deliberations on freedom of association. Over the last decade, freedom of association has been transformed in many of the jurisdictions that had attracted Wedderburn's earlier withering assessment. This jurisprudence has recognized trade unions as actors with their own independent constitutional rights, alongside the constitutional rights of workers themselves. ${ }^{61}$

One effect of this rise in freedom of association's general prestige amongst labor lawyers has been the eclipse of subsidiarity as a normative inspiration for labor law reform. Does this mean that the subsidiarity principle should be treated as having been superseded by the right to freedom of association as a reference point for labor lawyers? In my view, to turn away from the subsidiarity principle now would be a big mistake. Freedom of association is concerned with the protection of groups and collective activities. It must therefore be informed by a rational account of the nature of groups and group action, the value of groups, and the relationship between the group's agency and the agency of its individual members. Subsidiarity provides a deep and compelling engagement with those issues. It thus provides a valuable corrective to some of the missteps that can occur when regulatory choices about freedom of association are based upon faulty understandings of group phenomena. In this way, subsidiarity should be regarded as a structuring principle for freedom of association: complementary to it, and anything but redundant.

In support of this complementarity, the remainder of this article will explore some influential philosophical work on freedom of association in labor law. This work has provided an important theoretical framework for the naissance of freedom of association as a labor right. Let us start, then, with one of Sheldon Leader's core claims about the nature of freedom of association, taken from the leading work Freedom of Association: $A$ Study in Labor Law and Political Theory:

A static conception understands it as a right to join groups per se. A dynamic conception sees it as a right to try to achieve something by way of association, where the goal to be achieved lies outside of the group and is not reached simply by the act of joining it. The first conception of the right sees it as protecting interests which can be satisfied by the fact that people come together, as is often true in families, religious meetings, and clubs. The second conception sees association as a method of coordinating interests for their more effective

was Demir v. Turkey [2008] ECHR 1345. For a discussion of the significance of this case, see K. D. Ewing and John Hendy, "The Dramatic Implications of Demir and Baykara," Industrial Law Journal 39 (2010): 2-51.

${ }^{60}$ Lord Wedderburn, "Freedom of Association or the Right to Organise? The Common Law and International Sources," Industrial Relations Journal 18 (1987): 244-54.

${ }^{61}$ See, for example, Wilson v. UK (2002) ECHR 552. 
advancement against the outside world. It follows that the first conception is satisfied once we allow people to form and to join associations per se. The second conception demands satisfaction in a more complex way: it calls not simply for the permission to form and to join groups, but also the opportunity under conditions that are not unfairly debilitating to act through them. ${ }^{62}$

This distinction between "static" and "dynamic" seems to neatly capture the shifts that have occurred in changing judicial constructions of freedom of association. The older approach, which emphasized the individual's basic right to be a trade union member, reflected this "static" conception. The newer approach, based on an expanding frontier of collective freedoms such as a right to strike, reflects the "dynamic" conception. For Leader, this "dynamic" approach is preferable. Freedom of association is concerned with protecting individuals so that they can do things together with others. If individuals are free to bargain individually, they should be free to bargain collectively. If individuals are free to withdraw their labor individual, they should be free to do so collectively. And so forth. It is the individual's freedom to do things with others that is the distinctive concern of freedom of association, ensuring symmetry between individual actions and their collective exercise. ${ }^{63}$

On its face, this core claim provides a compelling and liberating vision of freedom of association. Nevertheless, I want to suggest that it is problematic for four reasons. Those reasons become clearer once we reflect back on the general account of groups and their contribution to human flourishing that underlies the subsidiarity principle.

\section{A. The Dynamic Nature of Groups}

We have already noted that Leader develops an argument in favor of the "dynamic" conception of freedom of association. Insofar as this encompasses protection for core trade union activities, that is the correct end-point. The misstep is in the starting assumption that there is any meaningful distinction to be drawn at all between "static" and "dynamic" association. That is a mistake. It is natural enough, perhaps, for a lawyer to take this distinction as a starting point, for it is so deeply embedded in the judicial mind-set, especially in many of the older cases on freedom of association. Yet there is no such thing as a "static" association, as Finnis's theoretical account of the nature of group existence makes clear. The reasoning in the older cases simply betrays faulty philosophical thinking about groups.

Leader describes the "static" conception as being especially relevant to families and religious associations, where it is simply the coming together as members of the group that satisfies their relevant interests. So some types of group, such as those based on religiosity

\footnotetext{
${ }^{62}$ Sheldon Leader, Freedom of Association: A Study in Labor Law and Political Theory (New Haven: Yale University Press, 1992), 27.

${ }^{63}$ This understanding of freedom of association has been very central to the work of Brian Langille, whose work on freedom of association in the Canadian context has been highly influential in academic and judicial debate. For the signature piece, see Brian Langille, "The Freedom of Association Mess: How We Got into It and How We Can Get out of It," McGill Law Journal 54 (2009): 177-215.
} 
or intimacy or sociability, are "static." Other groups, for example trade unions, are "dynamic" in being directed at the pursuit of external goals. This seems to involve some slippage back into the difficulties explored earlier, and the rather elusive distinction between "instrumental" and 'non-instrumental' associations. But leaving that worry to one side, there is a more fundamental objection to this analysis.

In his reflections on the nature of community, Finnis has argued that the existence conditions of any human group require "over an appreciable span of time, a co-ordination of activity by a number of persons, in the form of interactions, and with a view to a shared objective." ${ }^{\prime 4}$ This reflects sensitivity to the underlying value of subsidiarity, of persons doing things, using their own imagination and initiative to participate in forms of life that will often be based on cooperation and coordination with others. This coordination of activities around shared purposes is indisputably a feature of even the most intrinsic of associations. In friendships, the coordination is undertaken for the sake of the friend's well-being. This coordination will often consist in complex activities such as shared recreational and leisure pursuits, and mutual support and help in times of need. Like marriage, this intrinsic form of association is very far from being static. In more instrumental arrangements, such as a business venture, the coordination may be undertaken for the sake pursuing external goals where the members may be indifferent to each other's individual objectives. Here again, though, the coordination of individual action is a central feature of the association's existence. Without coordinated actions, the association is unlikely to prosper as an instrument to the realization of the members' shared goals.

While the nature of the common good of the association is quite different in each case, the need for shared purposes and coordinated activities is a fundamental requirement of any association's existence. To the extent that the "static" conception of freedom of association isolates the fact of membership as sufficient for some associations, it rests upon a basic mistake about the nature of groups. Obviously, the purposes and the character of the members' coordinated actions will vary depending upon the nature of the goods that are being pursued: families, neighborhood associations, social clubs, religious denominations, trade unions and universities all differ greatly in this respect. Nevertheless, the existence of all groups is constituted by coordinated actions directed at shared purposes. Since all groups must be understood as being constituted by coordinated actions in pursuit of purposes shared by members of the group, all groups must be understood as "dynamic." The category of 'static' association is empty. To give it any credence at all risks conferring unwarranted legitimacy on some of the older cases on freedom of association that are based upon this "static" conception.

B. Freedom of association and legal intervention

The preceding point about "static" association is something more than a conceptual quibble. It has important political implications, for the "static" account is also aligned with a minimalist conception of the role of the law in supporting associations. Leader's account of "static" association implies that the non-intervention of the state will suffice to respect the right. Once we allow people to form and to join associations per se, "static" freedom of

${ }^{64}$ Finnis, Natural Law and Natural Rights, 153. 
association is respected, whereas respect for "dynamic" associations "demands satisfaction in a more complex way." ${ }^{65}$

Would a simple permission from the state ensure respect for the basic right to be a member of an association? That seems unlikely. The state may be under a duty to protect citizens from interference by employers who might seek to coerce or interfere with the choice to join a trade union. This might necessitate the implementation of a complex set of rights protecting individuals from refusals of employment, bribes and financial inducements, detriment, and dismissal on the ground of trade union membership. These individual rights may need to be supported by a regulatory regime to tackle blacklisting practices, and the misuse of information by organized groups of employers where information is shared and used to deny employment opportunities to trade unionists. It will also be necessary to provide the trade union itself with certain basic rights so that it is capable of functioning as a coordinating entity: without a group that exists, there would be nothing for the individual to join. ${ }^{66}$ This requires a mechanism for enabling the trade union to acquire some form of legal personality, so that it can hold property, enter into contracts on its own account, and engage in legal proceedings. The ability to enter into contractual arrangements with members may be particularly important in the trade union context, because the contract of membership typically encompasses disciplinary rules and procedures. This supports the union's internal authority so that it is better able to coordinate its members, and to maintain social norms of solidarity in the face of external threats and the usual temptations of defection and free-riding. The legal system may also need to regulate the interactions between groups where there are competing claims of membership solidarity. For example, in Sindactul Pastorul Cel Bun'v. Romania the ECtHR subordinated the right of priests to form their own trade union to the religious authority of the Orthodox Church. ${ }^{67}$ The Church had successfully challenged the registration of the dissident trade union in the domestic courts. The "autonomy" of the Orthodox Church to maintain its preferred form of life through religious authority was given strong protection under Article 9 of the ECHR which protected freedom of religion. The seemingly simple right to be a trade union member required complex legal machinery to mediate the claims of conflicting group loyalties.

All of this envisages a highly complex structure of legal regulation as a basis for the fundamental right to trade union membership. This recognition is important for two reasons. First, it reinforces the perfectionist reading of the subsidiarity principle. The "laissez-faire" view that civil society will just "take care of itself" without extensive legal support is untenable. The complex nature of groups as based on coordinated activities around shared purposes necessitates a complex legal structure of individual and collective rights. This seems to be true even for the implementation of the most basic right to join a group. A vibrant and diverse civil society requires strong perfectionist state support through coordinating legal norms for its maintenance.

\footnotetext{
${ }^{65}$ Leader, Freedom of Association.

${ }^{66}$ Joseph Raz makes precisely this point about freedom of religion: without the secure existence of religious communities as a public good, individual freedom of religion would be undermined: see Raz, The Morality of Freedom, 251.

67 [2013] ECHR 646.
} 
Secondly, Leader has given us no reason to accept that "dynamic" freedom of association requires more complex and demanding legal intervention than 'static' freedom of association. It is not clear why legal protection of a "right to strike" would be any more or less complex or demanding than legal protection of a "right to form and join a trade union." This is politically significant, for at least some of the reservations that have been articulated about the judicial development of 'dynamic' rights, such as the right to collective bargaining, seem based on the assumption that such rights (in Leader's words) 'demand satisfaction in a more complex way." Where rights demand "more complex" satisfaction, this might generate institutional concerns about the appropriate limits of the judicial role in a constitutional democracy. ${ }^{68} \mathrm{Or}$, where this complexity is manifested in a larger set of correlative duties, we might be concerned with the knock-on effects of complex rights on the personal freedom of duty-bearers. ${ }^{69}$ Given the complex nature of the right to form and join trade unions, the recognition of "dynamic" rights such as the right to strike seems to cross no Rubicon in this respect. 'Dynamic' freedom of association gives us no extra cause for concern. Subsidiarity, and its theory of group action, helps to explain why the coyness about 'dynamic' rights over "static" rights is misplaced.

\section{The nature of group action}

A third area of controversy has been whether freedom of association extends to trade unions as right-holders engaged in their own protected 'inherently collective' activities. ${ }^{70}$ This particular ship has already sailed in the ECtHR and the Supreme Court of Canada: the rights of trade unions are treated as independently grounded, rather than trade unions piggy-backing derivatively on the constitutional protection of individual rights. ${ }^{71}$ Building upon Leader's philosophical arguments, Brian Langille has argued that such a move is mistaken:

If I have a right to bargain collectively, the fact that collective bargaining is "an inherently collective activity" does not and cannot enter into the matter. Once I have exercised my right to freedom of association, I have indeed ended up in the very circumstance that the right is designed to secure: participation in a group or collective, which by definition I cannot do alone. This individual conception of the right can, and does, perform all of the work required. Indeed, without a mooring in concern for real people, it is hard to see why groups are important. ${ }^{72}$

\footnotetext{
${ }^{68}$ For an interesting elaboration of this institutional point, see Brian Langille, "Why Are Canadian Judges Drafting Labour Codes—and Constitutionalizing the Wagner Act Model?," Canadian Labour and Employment Law Journal 15 (2010): 101-28.

${ }^{69}$ Langille, “The Freedom of Association Mess," 199-201.

70 The notion of "inherently collective" activity comes from Chief Justice Dickson's famous dissent in Reference Re Public Service Employee Relations Act (Alta.) [1987] 1 S.C.R. 313, 38 D.L.R. (4th) 161 (known as the "Alberta Reference").

${ }^{71}$ The fact that trade unions are independent right-holders under Art. 11 ECHR was recognized in Wilson v. UK (2002) ECHR 552. The Supreme Court of Canada has also confirmed that the Canadian Charter extends its protection to groups as well as individuals in Mounted Police Association of Ontario v. Canada (Attorney General) [2015] 1 S.C.R. 3, para 64.

${ }^{72}$ Langille, “The Freedom of Association Mess,” 186.
} 
Langille's final normative point is surely right: the ultimate point of all associations is to assist individuals to lead lives of value. ${ }^{73}$ Langille argues that the fundamental moral priority of persons leads to two basic consequences for freedom of association. First, that "inherently collective activity" "does not and cannot enter into the matter" of what is protected by freedom of association. All of the matters with which we might be concerned will consist of a series of individual acts that are undertaken collectively. To the extent that the category "inherently collective activity" implies that some group acts are not straightforwardly divisible into their component individual acts, this is an unhelpful mystification. Secondly, Langille thinks that the individual right "can, and does, perform all of the work required." Why might this be so? Perhaps Langille thinks that group rights obscure the point that only persons have ultimate moral value. Or perhaps Langille thinks that group rights are somehow less "fundamental" than individual rights or might otherwise threaten individual interests. ${ }^{74}$ Whatever the reasons, Langille does not believe that there are fundamental group rights warranting special constitutional protection.

The underlying theory of group action in Finnis's account of subsidiarity demonstrates the falsity of this picture, and indicates another crucial way in which subsidiarity operates as a corrective to faulty thinking about freedom of association. On Finnis's account, we may readily accept (i) that only persons have ultimate moral value; but that (ii) it is perfectly intelligible to treat some group actions as "inherently collective." As such, the subsidiarity principle provides powerful support for the notion of "inherently collective activities" in the constitutional jurisprudence of the SCC. While there is more argumentative work to be done in establishing the existence of group rights, the insights of the subsidiarity principle at least block out some of the main arguments levelled against group rights by Langille. At the very least, it demonstrates how the protection of 'inherently collective' activities under freedom of association is a reasonable constitutional choice.

Let us begin with the fundamental value of subsidiarity. According to Finnis, it is "to help the participants in the association to help themselves." 75 This requires that persons "do certain things, that one should act, with integrity and authenticity." ${ }^{76}$ In this way, individuals are enabled to participate in the basic goods and to constitute themselves through deliberation, choice and activity, rather than being the passive consumers of endstates and experiences provided by remote external agencies. Wherever possible, we should make our own way in the world, forging our own lives in cooperation with others. That is what it means to lead a life. This has led Finnis to be skeptical about theories of corporate personality that postulate the group as a real entity with a real personality. ${ }^{77}$ This skepticism is well-justified. The attribution of personality to groups "is a distracting metaphor in a

\footnotetext{
${ }^{73}$ On this fundamental normative point, see John Finnis, "The Priority of Persons," in Oxford Essays in Jurisprudence, $4^{\text {th }}$ series, ed. Jeremy Horder (Oxford: Oxford University Press, 2000), 1-15.

${ }^{74}$ For an acute discussion of these matters, see L Green, 'Two Views of Collective Rights' (1991) 4

Canadian Journal of Law and Jurisprudence 315.

${ }^{75}$ Finnis, Natural Law and Natural Rights, 146.

${ }^{76}$ Ibid., 147.

${ }^{77}$ John Finnis, "Persons and their Associations," in Finnis, Intentions and Identity: Collected Essays: Volume II (Oxford: Oxford University Press, 2011), 92-99.
} 
realistic moral and political analysis of human associations and their actions." 78 This is because groups do not possess a substance and rational nature beyond "the many orderings of human association which we call groups-nothing except the people who are members." ${ }^{79}$ So far, there is nothing here that is inconsistent with Langille's account of the morality of association. This is just as well, for the moral priority of persons seems to be just the right starting-point.

Does it follow from this that collective acts must always be reducible to the component acts of individuals? Langille certainly seems to think so. However, some recent philosophical work on the nature of group rights and group action has debunked this reducibility thesis very convincingly. For example, Dwight Newman has drawn an important distinction between the supervenience of collectivities on the acts of individual members and reducibility of the collectivity to the individual acts that constitute the group. ${ }^{80}$ Newman gives the example of individual voting on a university committee leading to a decision to close down a department. The electoral outcome is of course determined by a series of individual voting choices. The decision itself may nevertheless attract moral comment in its own right: "There is an ineliminable reference to the collectivity in our moral commentary, and that is sufficient to make a prima facie case that the collectivity's actions can be morally analysed independently of the individual acts on which they supervene in some respects." ${ }^{\prime 11}$ Finnis's account of subsidiarity supports this distinction between supervenience and reducibility. It is certainly the case that group acts cannot be divorced from the coordinated individual activities of the group's members; that would of course be nonsensical. The misstep in Langille's theory of freedom of association is to treat this as closing off the possibility that the group itself may nevertheless be acting. Finnis explains this notion of group action through the group's adoption and implementation of a plan or "proposal" on what is to be done: "the unity of action coordinated according to this adopted proposal is the unity of a group act distinguishable (albeit inseparable) from the activities of individuals...pursuant to a single, public proposal." 82

Langille does not deny that there are certain things that cannot but be done collectively: the performance of a choir; or collective bargaining; or participation in a language community. He does deny that these group acts can be understood as "inherently collective," that is as group acts that are not reducible to their component individual acts: collective bargaining is individual bargaining undertaken by a collectivity of individual workers; the performance of a choir is individual singing undertaken by a collectivity of singers; a strike is an aggregation of individual withdrawals of labor undertaken by a group of workers, and so forth. It is of course true that the group act cannot be detached from the acts of individual participants. If there are no individual workers acting in coordination in the pursuit of an adopted plan to secure better terms of employment, there will be no collective bargaining. In other words, and to use the helpful distinction drawn by Newman, group acts are supervenient on the acts of individual members of the group. Pace Langille, however, it is quite possible to conceive of group acts that are not reducible to individual

\footnotetext{
78 Ibid., 98.

79 Ibid.

${ }^{80}$ Dwight Newman, Community and Collective Rights (Oxford: Hart Publishing, 2011), 35-42.

81 Ibid., 40.

${ }^{82}$ John Finnis, "Introduction," in Finnis, Intentions and Identity (Oxford: Oxford University Press, 2011), 11.
} 
acts. That is, there is supervenience without reducibility. Take the example of a team performance at sport. One can marvel at the fluency of the team's coordinated performance, manifesting a well-executed strategy that results in a victory. The performance of the whole team may be much more admirable than the sum of its individual players' performances. The action of the team itself, as distinct from its individual players, is an appropriate object of independent evaluation; even though the team's performance can never be independent of the coordinated actions of individual players. In this sense, then, there are "inherently collective" actions that are not straightforwardly divisible into individual component contributions.

Finnis's theory of group action enables us to make sense of the character of the "right to strike" in countries like Germany, where the trade union itself is regarded as the relevant right-holder. In Finnis's terms, a strike as an "inherently collective" act may be understood as the adoption and implementation of a public proposal by the individual workers acting through the internal decision-making structures of the trade union. This "unity of action coordinated according to this adopted proposal is the unity of a group act distinguishable (albeit inseparable) from the activities of individuals." ${ }^{83}$ Comparative labor lawyers would of course point to the varieties of strike laws in different legal regimes. Some legal systems specify the right to strike as an individual right, albeit one exercised collectively with others, and this is often a reflection of the legal culture, and the political and ideological character of the trade union movement. ${ }^{84}$ But none of this commits us to the view that the right to strike must be understood as a group right, even if Langille's account implies that it must be understood as an individual right. This would be a matter residing within the creative scope of determinatio, requiring a choice by the law-giver amongst different reasonable options. ${ }^{85}$ The value of Finnis's account is that it shows us how the configuration of striking or collective bargaining as an "inherently collective" activity is reasonable as a constitutional choice. There is nothing at all odd about a group act that is not straightforwardly reducible to a set of component individual acts. We can talk sensibly about the trade union's strike, whether it was a responsible exercise of a constitutional freedom, the trade union's right to strike, and so forth, quite independently of any moral appraisal of individual strikers. We can also appraise the acts of individual strikers independently of the trade union, especially where they act beyond the scope of the formulated plan.

Finnis's sophisticated account of group action is fully in alignment with Langille's view that "the primal aspiration of our labour law is to protect and to advance the interests of workers" as human persons. ${ }^{86}$ It commits us to no silly baggage about groups having a real personality or the priority of groups over persons in respect of ultimate value. While it is of course true that the notion of "inherently collective" acts does not establish the existence of group rights, it at least raises a significant doubt in Langille's claim that the

\footnotetext{
${ }^{83}$ Ibid.

${ }^{84}$ The most obvious example is the individual right to strike in France, which reflects the imperatives of a pluralist trade union movement divided along confessional and ideological lines. For discussion, see Alan Bogg, “The Hero's Journey: Lord Wedderburn and the 'Political Constitution' of Labour Law,” Industrial Law Journal 44 (2015), 345-346.

${ }^{85}$ On the idea of determinatio in natural law theory, see Robert P. George, "Natural Law and Positive Law," in The Autonomy of Law, ed. Robert P. George (Oxford: Oxford University Press, 1996), 321-34.

${ }^{86}$ Langille, "The Freedom of Association Mess," 188.
} 
"individual conception of the right can, and does, perform all of the work required." That does not seem to be true where "inherently collective" acts are concerned. The category of "inherently collective" acts is, moreover, a reasonable way of explaining group phenomena in many contexts of workplace collective action.

D. The special value of the strike as a form of self-constituting action

Why would we protect the right to strike as a fundamental right under freedom of association? Leader provides a clear and emphatic answer to this question.

Should the right to strike be understood, not as a means of respecting, but rather as a species of the right to freedom of association? There is a strong, basic reason for thinking that it should be: if we look closely at the structure of the two rights, we can see that they are aimed to prevent the same sort of injustice. This is the inequity involved in subjecting individuals to a blanket prohibition, an automatic disability, preventing them from acting together when they are each allowed to pursue the same objective when acting alone, and hence making them less free to do collectively what they are allowed to do individually. ${ }^{87}$

On this view, there is nothing special about the right to strike as a "species of freedom of association." We could multiply the "species of freedom of association" indefinitely: a right to play tiddly winks together; a right to read books together; a right to count blades of grass together; a right to protest together. The freedom at stake in freedom of association is the freedom to do something with others. For some scholars, this has evident attractions. It ensures "neutrality" in the constitution of fundamental rights. ${ }^{88}$ Courts and constitutionmakers should not take a stand on which exercises of freedom of association are valuable, or inconsequential, or worthless. That is for citizens to decide for themselves. An alternative approach to freedom of association rejects this neutrality. Certain exercises of freedom are given a focal normative position in freedom of association. Trade unions are often identified explicitly in freedom of association guarantees, whereas many other types of association are not. Increasingly, certain types of trade union right are given an elevated status in freedom of association, such as the right to bargain collectively and the right to strike. Is it possible to make coherent sense of this structure of priorities in freedom of association, or does it simply reflect the accidents of litigation strategies and political pressures brought to bear in constitutional drafting?

The subsidiarity principle provides an explanation for why the right to strike is regarded as an associational freedom of profound significance, whereas playing tiddly winks or counting blades of grass together is not. Collective bargaining and strike action constitute a distinctive form of human activity where workers "help themselves by their own private efforts and initiatives. ${ }^{~} 99$ This is why collective bargaining and the right to

\footnotetext{
${ }^{87}$ Leader, Freedom of Association, 200.

${ }^{88}$ Ibid., 185.

${ }^{89}$ Finnis, Natural Law and Natural Rights, 169.
} 
strike are rightly identified as trade union freedoms of special value in freedom of association, for it is through voluntary self-organization that workers are able to help themselves through their own endeavors. Historically, labor lawyers were intensely preoccupied with the question of how substantive labor standards were formulated and implemented. This was a matter of political and moral significance rather than an issue of merely technical interest. It marked a preference for workers forging their own norms rather than being passive recipients of state support or employer paternalism. It was a way of achieving dignity and self-respect in the midst of the degradation and depredations of industrial capitalism. This is why the denial of collective bargaining and the right to strike are regarded as a serious injustice, for this denial disrupts the dignified efforts of workers to shape their own working lives, and in so doing to shape personal identity through selfconstituting action.

Recent jurisprudential developments in the Supreme Court of Canada (SCC) have reflected this sophisticated understanding of the freedom at stake in freedom of association. In Mounted Police Association of Ontario v. Canada (Attorney General) the Court was called upon to consider whether the imposition of a "Staff Relations Representative Programme," and a refusal to engage in collective bargaining with independent trade unions representing the police, was a violation of the right to freedom of association under section 2 (d) of the Canadian Charter. ${ }^{90}$ A majority of the Court concluded that this imposition of a mandated representative body constituted a "substantial interference" with freedom of association. In support of this holding, the Court articulated a sophisticated account of the special value of the freedom protected in 'freedom of association', drawing upon the earlier influential dissent of Chief Justice Dickson in the Alberta Reference:

The purpose of the constitutional guarantee of freedom of association is, I believe, to recognize the profoundly social nature of human endeavours and to protect the individual from state-enforced isolation in the pursuit of his or her ends...As social beings, our freedom to act with others is a primary condition of community life, human progress and civilized society. Through association, individuals have been able to participate in determining and controlling the immediate circumstances of their lives, and the rules, mores and principles which govern the communities in which they live...Freedom of association is most essential in those circumstances where the individual is liable to be prejudiced by the actions of some larger and more powerful entity, like the government or an employer. Association has always been the means through which political, cultural and racial minorities, religious groups and workers have sought to attain their purposes and fulfil their aspirations; it has enabled those who would otherwise be vulnerable and ineffective to meet on more equal terms the power and strength of those with whom their interests interact and, perhaps, conflict. ${ }^{, 91}$

In Mounted Police Association the SCC based its reasoning on what it described as a "purposive" conception of freedom of association. This "purposive" conception is

\footnotetext{
90 [2015] 1 S.C.R. 3.

${ }^{91}$ See n 70 above, 365-366, cited ibid., para [35].
} 
strongly aligned with the understanding of associational activity in the Finnisian theory of subsidiarity. Thus, in the words of the Court, "the guarantee of freedom of association empowers vulnerable groups and helps them work to right imbalances in society. It protects marginalized groups and makes possible a more equal society." ${ }^{92}$ In other words, the fundamental point of freedom of association is to empower groups, and in so doing to enable individuals to help themselves and each other through concerted action. It is in this sense, then, that freedom of association is properly described as "purposive," in the light of its special contribution to facilitating self-constituting action through participation in groups in civil society. The normative value of voluntary collective bargaining through freely formed associations of workers is the embodiment of self-help through cooperative action.

According to the SCC, the imposition of a representative scheme on workers undermined the elements of choice and independence upon which the value of freedom of association is based. The workers' freedom to choose a representative facilitates accountability and empowers workers to shape the collective goals pursued by their association: it ensures that "their voice will be conveyed to the employer by the people they choose." "The legal regime would accordingly need to protect "the ability to form and join new associations, to change representatives, to set and change collective workplace goals, and to dissolve existing associations." 94 Independence complements choice by ensuring that the association and its collective goals are autonomously directed by the workers themselves, rather than directed, manipulated or imposed by management or the state. This would necessitate "the freedom to amend the association's constitution and rules, the freedom to elect the association's representatives, control over financial administration and control over the activities the association chooses to pursue." ${ }^{95}$ Choice and independence ensure that the workers themselves are in charge of the "formation, direction or management" of their association, rather than this being usurped by the state.

The functional value of freedom of association in assisting workers to help themselves through collective action was also pivotal in the SCC's recent decision in Saskatchewan Federation of Labour $v$. Saskatchewan..$^{96}$ The provincial government introduced legislation that prohibited strike action in certain "essential" public services, nor was any substitute mechanism provided for those employees in a situation of bargaining impasse. The SCC held that this legislation violated freedom of association under the Charter because it constituted an unjustifiable interference with the right to strike. The right to strike was identified as an "indispensable component" of the right to a meaningful collective bargaining process. ${ }^{97}$ The basis for the SCC's conclusion that the right to strike was a protected through freedom of association reveals a common normative foundation shared with the majority judgment in Mounted Police Association. After citing Chief Justice Dickson's defense of 'purposive' freedom of association and its underlying values in the

\footnotetext{
92 Ibid., para [58].

${ }^{93}$ Ibid., para [87].

${ }^{94}$ Ibid., para [86].

95 Ibid., para [89].

${ }^{96}$ [2015] 1 S.C.R. 245.

${ }^{97}$ Ibid., para [3].
} 
Alberta Reference, ${ }^{98}$ Justice Abella justified the constitutional recognition of the right to strike in the following way:

The right to strike is essential to realizing these values and objectives through a collective bargaining process because it permits workers to withdraw their labour in concert when collective bargaining reaches an impasse. Through a strike, workers come together to participate directly in the process of determining their wages, working conditions and the rules that will govern their working lives...The ability to strike thereby allows workers, through collective action, to refuse to work under imposed terms and conditions. This collective action at the moment of impasse is an affirmation of the dignity and autonomy of employees in their working lives. ${ }^{99}$

Note the final sentence: exercising the right to strike at a bargaining impasse is "an affirmation of the dignity and autonomy of employees in their working lives." The ability to strike enables workers to lead an existence worthy of human dignity and autonomy by granting them a measure of collective control over the norms that regulate their working life. Workers cease to become passively dependent on state support or employer good will and engage with the vital task of shaping their own collective fate. As the most potent form of worker "self-help" through collective action, the right to strike empowers workers to contest injustice from a position of greater equality. Given the contribution of strike action in helping workers to help themselves through trade union association, the SCC identifies the right to strike as a freedom of special significance under freedom of association. This is because of its vital contribution to the life of self-constituting action, that one should "do certain things, that one should act, with integrity and authenticity; if one can obtain the desirable objects and experiences through one's own action, so much the better." ${ }^{100}$ Denial of the right to strike thus constitutes a violation of freedom of association that is of momentous significance. This is informed by an understanding of why human freedom is valuable and therefore why it is appropriate to identify some instances of freedom as more valuable and worthy of respect than others. In this sense, Dickson's conception of freedom of association is rightly described as "purposive," in its attentiveness to the proper ends of human activity in interpersonal associations. Subsidiarity provides a compelling and rich rationalization of what it is that is 'purposive' about freedom of association.

\section{Conclusion}

The contribution of John Finnis to the modern revival of natural law theory has been immense. His account of the subsidiarity principle stands as one of the most rigorous contemporary philosophical accounts of its nature and value. The article has suggested some modifications to Finnis's account of the subsidiarity principle, and it has argued for

\footnotetext{
${ }^{98}$ Ibid., para [33].

${ }^{99}$ Ibid., para [54].

${ }^{100}$ Finnis, Natural Law and Natural Rights, 147.
} 
a shift in emphasis to bring forth the perfectionist elements of subsidiarity more strongly. This reformulation nevertheless remains sympathetic to some broader themes in Finnis's moral and political philosophy. First, it rejects the alignment of some modern theories of freedom of association with an ideal of "neutrality." Such accounts advocate the need to avoid discriminating value judgements as to which particular exercises of freedom of association should be given special protection. In his discussion of freedom of speech, Finnis has argued that it "does not properly include exposure of the whole population, or even the whole adult population, to pornography, salacious advertising, and the filmed or cartooned glorification of cultural nihilism by cynically inhuman violence." ${ }^{101}$ The conception of freedom of association defended here, informed by the insights of the subsidiarity principle, similarly rejects "neutrality." Some forms of association and concerted activities are simply more worthwhile than others in their contribution to helping citizens to lead a valuable life. We should be unashamed in marking out those distinctions in our law and practice. A trade union committed to the principles of worker self-help is more worthy of our respect than an association of employers that compiles and circulates "blacklists" of trade unionists. Concerted blacklisting by employers is an attack on freedom of association: it is a harmful activity with no redeeming social value and does not warrant any protection under freedom of association. The practices of solidarity and self-help amongst workers committed to justice in the workplace are an especially valuable form of associative activity. "Neutrality" as even-handedness between the worthwhile and the worthless has no place in the configuration of fundamental human rights.

Secondly, nothing in this article should be read as a plea for the "constitutionalization" of labor rights, entrusting them to the processes of adjudication in constitutional courts. The normative enquiry into the constituent elements of freedom of association is quite distinct from the institutional enquiry into its appropriate political realization, and the respective roles of courts and legislatures in that task. It is a mistake to conflate these two enquiries. To describe freedom of association as a "statutory" rather than a "constitutional" right should not be read as any reflection of the normative importance attached to this right in a political culture. There may be sound reasons of institutional morality why we should entrust the specification of a fundamental right to ordinary legislation, amenable to democratic influence, rather than to constitutional courts. ${ }^{102}$ The balance of those reasons may well be different in different legal and constitutional cultures, or at different times. Finnis has rightly drawn attention to the constitutional context of Australia, where there is no entrenched Bill of Rights, yet a healthy rights-respecting culture prevails. ${ }^{103}$ In Australian labor law, for example, the right to freedom of association is implemented through legislation and entrusted to the ordinary democratic process. The fact that freedom of association is "constitutionalized" in Canada tells us nothing very much about the comparative state of freedom of association in

\footnotetext{
101 Finnis, "Reflections and Responses," 516.

102 John Finnis, "Human Rights and their Enforcement," in Finnis, Human Rights and Common Good Collected Essays: Volume III (Oxford: Oxford University Press, 2011),19-46.

${ }^{103}$ John Finnis, “Judicial Power: Past, Present and Future," lecture delivered at Gray's Inn Hall, 20 October 2015, (http://judicialpowerproject.org.uk/wp-content/uploads/2015/10/John-Finnis-lecture20102015.pdf).
} 
Australia and Canada, beyond the choice of legal technique for implementing the right. That would require us to engage with the substance of the right, and its realization in practice, rather than the legal form of its implementation.

Finally, we should never forget that the balance between constraint and perfectionism in subsidiarity is not simply an abstract philosophical enquiry. The subsidiarity principle inevitably takes its shape in specific political and historical contexts. In the middle decades of the twentieth century, when totalitarian regimes of various ugly political stripes had effectively dissolved the autonomous associations of civil society into the state apparatus, the primacy of constraint was warranted. From the collapse of Weimar through to the fall of the iron curtain across Europe, proponents of the subsidiarity principle were concerned to set strict limits on the coercive reach of the state in the voluntary associations of civil society. In the early decades of the twenty first century, the disintegration of mediating associations such as trade unions gives subsidiarity's perfectionist elements a pressing urgency. While our political judgements must always be cautious, state indifference rather than state interference now seems to present the biggest threat to Anglo-American civil society in the current context. 